\title{
Costus cuttings development on indolebutyric acid concentrations
}

\section{Desenvolvimento de estacas de Costus sob concentrações de ácido indolbutírico}

\author{
Petterson Baptista LUZ1; Thalita Neves MAROSTEGA ${ }^{2 *}$; Raphael Egues RANZANI ${ }^{3}$; \\ Edileuson Galvão ALEIXO³ ; Daizimary Stella de ARAÚJO²; Guilherme $\mathrm{KOCH}^{3}$; \\ Leonarda Grillo NENES ${ }^{1}$
}

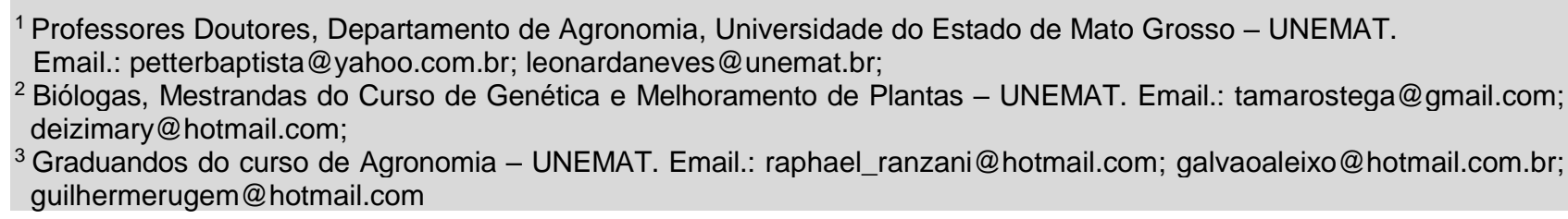

Recebido em: 16-07-2014; Aceito em: 1ㅇ--06-2015

\begin{abstract}
Cheilocostus speciosus plants are important ornamental plant that has been cultivated as a cut flower. This species is propagated by cuttings, but no studies on the factors that influence this process. Therefore, the main of this work was to study the effect of the indolebutyric acid (IBA) on the rooting of cuttings of Cheilocostus speciosus. The experiments were carried out University State de Mato Grosso, Campus of Cáceres/MT. The experimental design was completely randomized and the treatments six IBA concentrations $\left(0,200,400,600,800\right.$ e $\left.1000 \mathrm{mg} \mathrm{L}^{-1}\right)$, four replicates of 10 cuttings per replicate. The variables were observed: percentage of rooting, dead cuttings percentage, number of roots, length of roots, number of piles with bud, percentage of root callus. The indolebutyric acid concentration of $720 \mathrm{mg} \mathrm{L}^{-1}$ increased the rooting percentage, and the $685 \mathrm{mg} \mathrm{L}^{-1}$ one increased root number.
\end{abstract}

Additional keywords: asexual propagation; cuttings; Cheilocostus speciosus; IBA.

\section{Resumo}

A Cheilocostus speciosus é uma importante espécie ornamental, que vêm sendo cultivada como flor de corte. É propagada por estaquia, porém não há estudos sobre fatores que influenciam nesse processo. Assim este trabalho, objetivou estudar o efeito do ácido indolbutírico (AIB) no enraizamento de estacas de Cheilocostus speciosus. O experimento foi instalado na Universidade do Estado de Mato Grosso Campus de Cáceres/MT. O delineamento experimental utilizado foi inteiramente casualizado com seis concentrações de $\operatorname{AIB}\left(0,200,400,600,800\right.$ e $\left.1000 \mathrm{mg} \mathrm{L}^{-1}\right)$, quatro repetições e 10 estacas por repetição. As variáveis analisadas foram: porcentagem de enraizamento, porcentagem de estacas mortas, número médio de raízes por estaca, comprimento da maior raiz, número de estacas com broto, porcentagem de raiz com calo. $O$ ácido indolbutírico foi efetivo para aumentar a porcentagem de enraizamento na concentração de $720 \mathrm{mg} \mathrm{L}^{-1}$; maior número de raízes foram obtidos na concentração de $685 \mathrm{mg} \mathrm{L}^{-1}$.

Palavras-chave adicionais: AIB; Cheilocostus speciosus; estaquia; propagação assexuada.

\section{Introduction}

The Costaceae family, belonging to the Zingiberales order, consists of about 110-115 species. This order consists of Costus, Monocostus, Dimerocostuse and Tapeinocheilas genera, which are generally found in tropical and subtropical areas, rain forests and other humid environments (Araújo \& Oliveira, 2007). Costus, the largest genus, has pantropical distribution, with its highest diversity focused in the neotropical region (about 40 spp.), with 25 species in tropical Africa and about five species in Southeast Asia (Specht et al., 2001).

Economically, the family still has little importance, but intensification of studies and its potential dissemination will certainly contribute to its expansion. In recent years, Costaceae species cultivation as cut flower has been intensified, and Cheilocostus speciosus species is one of the most cultivated species for that use (Castro et al., 2012). According to the authors, propagation may be from rhizome section, cuttings and seeds. However, there is no information on rooting percentage and success rates for propagation through cuttings.

Cuttings rooting may be related to several factors, such as the species to be cultivated, cutting position in the branch, lignification degree, reserves amount and tissue differentiation, presence or absence 
of leaves in the cuttings. Environmental conditions in which cuttings are conducted are also important, such as substrate type, humidity, temperature, irrigation and lighting (Manuad, 2004; Azevedo et al., 2009). Fachinello et al. (2005) stated that auxin play an important role on cuttings rooting, with the main effect being linked to its action on root primordia induction. Auxin exogenous application also provides higher percentage, speed, quality and cuttings rooting uniformity.

The substrate, medium where cultivated plant roots are developed, may interfere in the cuttings rooting process (Fachinello et al., 2005) and influence grown roots quality and rooting percentage.

Several substrates may be used in cutting, such as sand, rice hulls, soil, humus, vermiculite, coir and the mixture of them (Luz et al., 2007). In general, vermiculite has promoted good survival rates and growth characteristics for various species (Roberto et al., 2004; Althaus et al., 2007; Pacheco \& Franco, 2008). Besides the substrate, the cutting roots forming process may also be associated with the plant hormone and growth regulator. In cutting, auxins produced by young leaves and buds naturally move to the bottom of the cutting, increasing its concentration in the cut base, along with sugars and other nutrients. In many ornamental plants, rooting is maximized by exogenous auxin application, like Bauhinia $x$ blakeana (Mazzini et al., 2013), Malvaviscus arboreus (Loss et al., 2009) and Allamanda cathartica (Loss et al., 2008).

The indolebutyric acid (IBA) is probably the most used synthetic auxin, because it is not toxic to most plants. Moreover, it is quite effective and stable to a large number of species, being less susceptible to auxin degradation enzyme systems action (Pires \& Biasi, 2003).

Some studies have reported IBA beneficial effect on ornamental plants cutting rooting, highlighting the studies by Sarzi \& Pivetta (2005), who worked with roses cuttings (Rosa spp.); Ribeiro et al. (2007), who evaluated quaresmeira cuttings (Tibouchina fothergilae Cogn); and Loss et al. (2008; 2009), who assessed Allamanda (Allamanda Cathartic L.) and Malvaviscus (Malvaviscus arboreus Cav.) cuttings.

Therefore, the objective was to evaluate the indolebutyric acid (IBA) effect on Cheilocostus speciosus cuttings rooting.

\section{Material and methods}

The experiment was conducted in the experimental area belonging to UNEMAT, located in the city of Cáceres-MT, from July to September 2013. The region has Tropical climate, with an average altitude of $118.0 \mathrm{~m}, 1^{\circ} 04^{\prime} 33^{\prime \prime} \mathrm{S}$ latitude and $57^{\circ} 39^{\prime} 10^{\prime \prime} \mathrm{W}$ longitude, with an average annual temperature of $32.4^{\circ} \mathrm{C}$, in which temperatures of $40^{\circ} \mathrm{C}$ can occur (Neves et al., 2011).

Herbaceous cuttings of $10 \mathrm{~cm}$ long were used, which were taken from the medium part of
Cheilocostus speciosus stock plant branches, with all leaves being removed, leaving two buds per cutting. After its preparation, cuttings were submitted to IBA application, through rapid immersion (10 seconds) of its basal portion. Afterwards, cuttings were immediately placed for rooting in plastic trays $(30 \times 21 \times 6.5 \mathrm{~cm})$ containing washed sand as substrate, which was previously sterilized. The test was conducted in greenhouse with $70 \%$ shading and irrigation was done daily, three times a day.

Regarding IBA hydroalcoholic solution preparation, first, dosages were determined (IBA) for each treatment, with its weighing in semi-analytical balance and dilution in $50 \mathrm{~mL}$ alcohol. After IBA was dissolved, the volume was completed to $1000 \mathrm{~mL}$ with distilled water, reaching the desired concentrations.

The experimental design was completely randomized, with six treatments and four repetitions with 10 cuttings per repetition. Treatments were formed by six IBA concentrations: 0, 200, 400, 600, 800 and $1000 \mathrm{mg} \mathrm{L}^{-1}$.

Evaluation was performed at 53 days after cutting, with the number of rooted cuttings, number of dead cuttings (calculating the percentage of rooting and death thereafter), number of roots, largest root length, number of cuttings with sprouts and percentage of cuttings with callus being recorded. For this purpose, cuttings that had at least $2 \mathrm{~mm}$ length radicle were considered rooted (Hadas, 1976).

Data for each variable were subjected to analysis of variance, and in case of significance, to polynomial regression analysis, using the SISVAR program (Ferreira, 2008).

\section{Results and discussions}

Rooted cuttings percentage set to the quadratic model regarding IBA concentration increases (Figure 1). Rooted cuttings percentage increased up to the concentration of $720 \mathrm{mg} \mathrm{L}^{-1}$ IBA, with $85.32 \%$ maximum rooting.

It was also observed through Figure 1 that the lowest IBA concentrations, from 0 to $200 \mathrm{mg} \mathrm{L}^{-1}$, although promoting rooting percentage increase in the extent to which there is an increase in the used dose, was not as efficient as the use of higher concentrations, between 600 and $1000 \mathrm{mg} \mathrm{L}^{-1}$ IBA.

Some authors reported the need for different concentrations and behavioral variations between species, cultivar and type of used cutting. Lemes et al. (2001), while studying rosemary seedlings at concentrations of 0,50 and $100 \mathrm{mg} \mathrm{L}^{-1}$ IBA, had not received answers to this growth regulators concentration.

Pereira et al. (2012) observed higher Alamanda cathartica cuttings rooting when they were submitted to the application of $250 \mathrm{mg} \mathrm{L}^{-1}$ IBA. Gratieri-Sossella et al. (2008) had higher Erytrina cristagalli cuttings rooting using $1000 \mathrm{mg} \mathrm{L}^{-1}$ IBA concentration, coinciding with the highest concentration used in this study. 


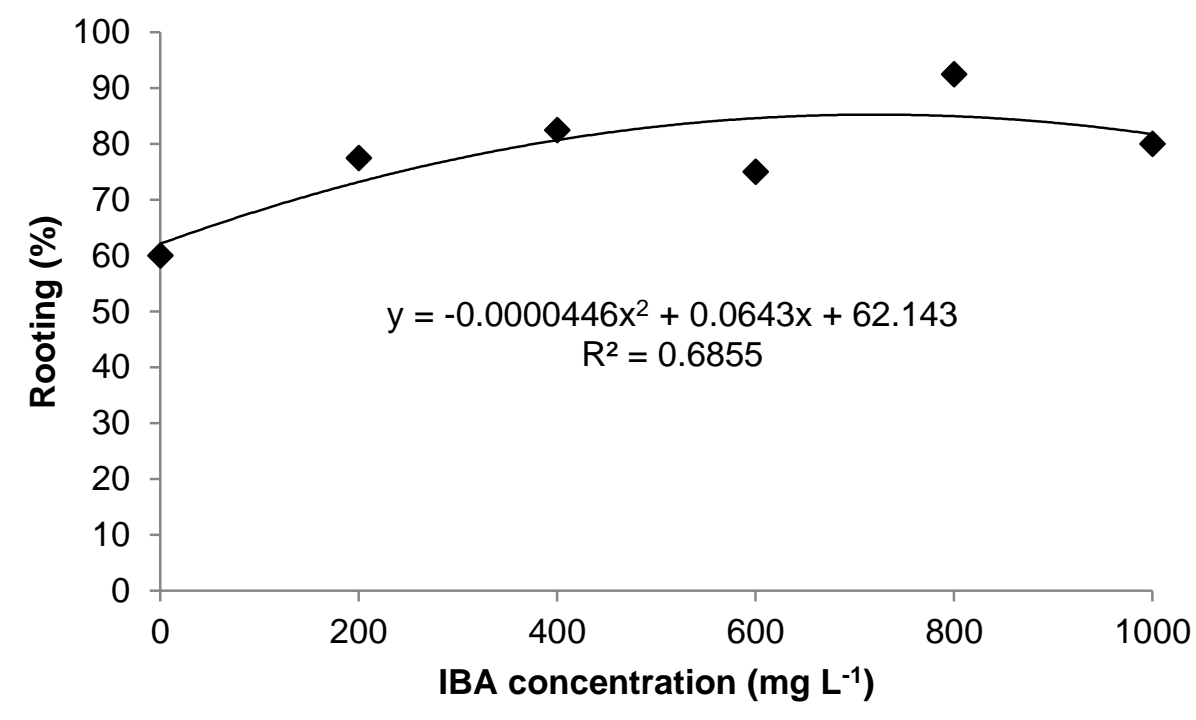

Figure 1 - Cheilocostus speciosus rooted cuttings percentage depending on indolebutyric acid (IBA) concentration.

It can be seen that IBA application promoted positive effects on Cheilocostus speciosus cuttings rooting, accelerating a new plant formation. The same effect has been confirmed in other species by Lima et al. (2008), Pizzatto et al. (2011) and Santos et al. (2011).

Hartmann et al. (2011) stated that IBA, when exogenously applied, mainly operates in meristematic centers formation, or activating pre-existing meristems, promoting root primordia formation and subsequent adventitious roots development. However, increasing IBA exogenous concentration stimulates rooting up to a maximum value. From this maximum value, regulator concentrations increase begins to have inhibitory effect (Fachinello et al., 2005), what was observed in the setting of second degree regression equations (Figures 1 and 2).
In addition, various factors, such as concentration, year period, cutting position in the branch and species can affect IBA application cutting response regarding rooting (Fachinello et al., 2005; Pizzatto et al., 2011, Santos et al., 2011).

Quadratic regression adjustment, in which the number of roots is increased to a concentration of $685 \mathrm{mg} \mathrm{L}^{-1}$, corresponding to 8.56 root/seedling (Figure 2), was observed. Other authors found an increase in the number and average length of roots with IBA use in different species, what was not observed in this study, including Carvalho et al. (2005) and Pivetta et al. (2012). However, Souza et al. (2009) and Lone et al. (2010) have not observed IBA use positive effect in the number of Toonaciliata and Rhododendron simsii seedling roots, respectively.

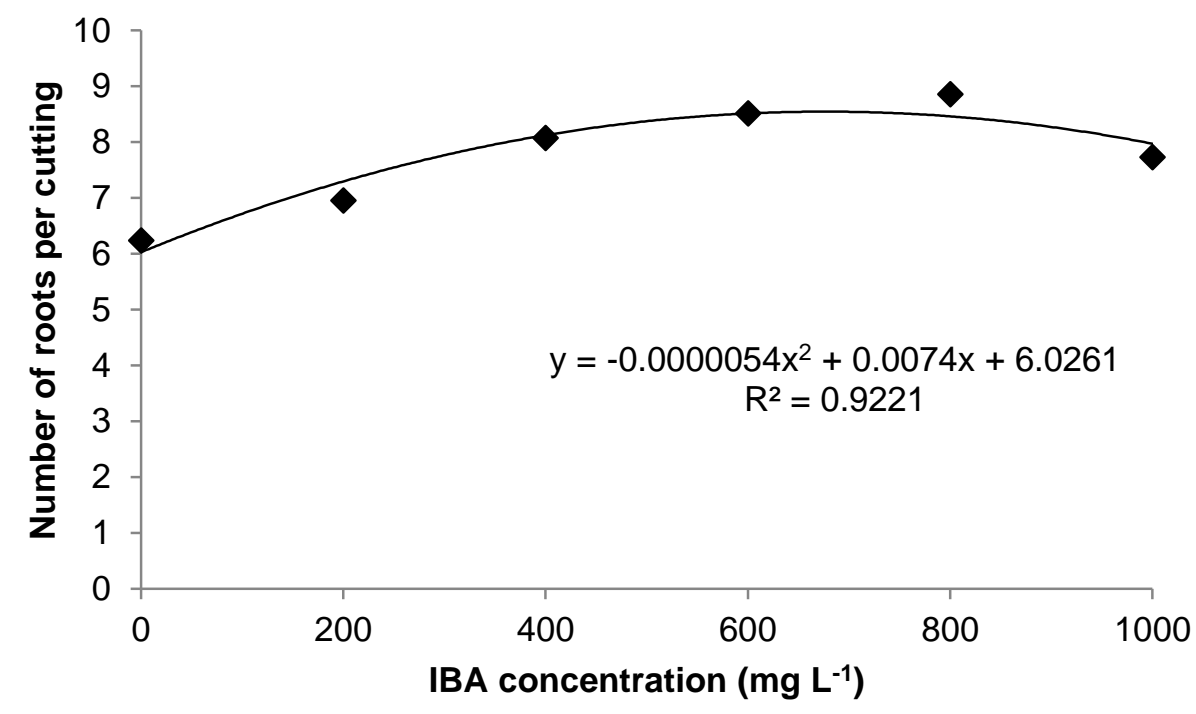

Figure 2 - Number of roots per Cheilocostus speciosus cutting, subjected to different indolebutyric acid (IBA) concentrations. 
These results show that IBA significantly stimulated roots emission and not their development. According to Hartmann et al. (2011), IBA plant growth regulator exogenous application stimulates root initiation on vegetative propagation, but may compromise its development in high concentrations.

In general, auxin treatments tend to be rapid and effective when doses with higher than $1500 \mathrm{mg} \mathrm{L}^{-1}$ concentrations are applied (Cuquel et al., 1992). However, species respond differently to the application of growth regulators, on the basis of auxin and cytokinin endogenous balance in the plant (Dias et al., 2011).

Observing the high percentage of rooted cuttings and number of roots $(60 \%$ and 6.24 roots/seedling) in the treatment with IBA absence, it can be inferred that auxin endogenous levels in Cheilocostus speciosus are enough to stimulate plant development. Baldotto et al. (2012) also have investigated adventitious roots formation in croton cuttings (Codianeum varie atum $\mathrm{L}$. Rumph), even in the absence of indolebutyric acid (IBA) doses application.

\section{Conclusions}

Indolebutyric acid was effective to increase the number of roots in the concentration of $685 \mathrm{mg} \mathrm{L}^{-1}$, corresponding to 8.56 roots/seedling. The highest rooting percentage was obtained at a concentration of $720 \mathrm{mg} \mathrm{L}^{-1}$, corresponding to $85.32 \%$.

\section{References}

Althaus MM, Leal L, Silveira F, Zuffellato-Ribas KC, Ribas LLF (2007) Influência do ácido naftaleno acético e dois tipos de substrato no enraizamento de estacas de jasmim-amarelo. Revista Ciência Agronômica 38(3):322-326.

Araújo FP, Oliveira PE (2007) Biologia floral de Costus spiralis (Jacq.) Roscoe (Costaceae) e mecanismos para evitar a autopolinização. Revista Brasileira de Botância 30(1):61-70.

Azevedo CPMF, Ferreira PC, dos Santos JS, Pasin LAAP (2009) Enraizamento de estacas de cana-do-brejo. Bragantia 68 (4):909-912.

Baldotto LEB, Baldotto MA, Soares RR, Martinez HEP, Venegas VHA (2012) Adventitious rooting in cuttings of croton and hibiscus in response to indolbutyric acid and humic acid. Revista Ceres 59 (4):476-483.

Carvalho AS, Graf CCD, Violante AR (2005) Produção de material básico e propagação. In: Mattos Júnior, D. et al. (Ed.) Citros. Campinas: Instituto Agronômico e Fundag. p.279-316.

Castro CEF, Gonçalves C, Moreira SR, Faria AO (2012) Costus e outras espécies da família Costaceae. In: Paiva PDO, Almeida EFA. Produção de flores de corte. Lavras: UFLA. p.178-221.
Cuquel FL, Granja P, Minami K (1992) Avaliação do enraizamento de estacas de crisântemo (Chrysanthemum morifolium L.) cv. White Reagan 606 tratadas com ácido indolbutírico (IBA). Scientia Agricola 49(1):15-22.

Dias MM, Chalfun NNJ, Coelho SJ, Santos VA (2011) Meios de diluição e concentrações de ácido indolbutírico no enraizamento de estacas de cerejeira ornamental. Tecnologia e Ciência Agropecuária 5(4): 39-43.

Fachinello JC, Hoffmann A, Nachtigal JC (2005) Propagação de plantas frutíferas. Brasília: Embrapa Informações Tecnológicas, 221p.

Ferreira DF (2008) SISVAR: um programa para análises e ensino de estatística. Revista Symposium 6(1):36-41.

Gratieri-Sossella A, Petry C, Nienow AA (2008) Propagação da corticeira do banhado (Erythrina cristagalli L.) (Fabaceae) pelo processo de estaquia. Revista Árvore 32(1):163-171.

Hadas A (1976) Water uptake and germination of leguminous seeds under changing external water potential in osmotic solution. Journal of Experimental Botany 52(1):480-489.

Hartmann HT, Kester DE, Davies RT, Geneve RL (2011) Plant propagation: principles and practices. 8 ed. New Jersey, Prentice Hall. 915p.

Lemes C, Rodríguez C, Acosta L (2001) Multiplicación vegetativa de Rosmarinus officinalis L. (Romero). Revista Cubana de Plantas Medicinales 6(3):79-82.

Lima DM, Silva CL, Ritter M, Biasi LA, Zanette F, Zuffellato-Ribas KC (2008) Substratos e auxinas no enraizamento de estacas caulinares de espinheirasanta. Scientia Agraria 9:85-89.

Lone $A B$, Unemoto LK, Yamamoto LY, Costa L, Schnitzer JÁ, Sato AJ, Ricce WS, Assis AM, Roberto SR (2010) Enraizamento de estacas de azaleia (Rhododendron simsii Planch.) no outono em AIB e diferentes substratos. Revista Ciência Rural 40(8):1720-1725.

Loss A, Teixeira MB, Assunção GM, Haim PG, Loureiro DC, de Souza JR (2008) Enraizamento de estacas de Allamanda cathartica L. tratadas com ácido indolbutírico (AIB). Revista Brasileira de Ciências Agrárias 3(4):313-316.

Loss A, Teixeira MB, Santos TJ, Gomes VM, Queiroz LH (2009) Indução do enraizamento em estacas de Malvaviscus arboreus Cav. com diferentes concentrações de ácido indolbutírico (AIB). Acta Scientiarum Agronomy 31(2):269-273. 
Luz PB, Paiva PDO, Landgraf PRC (2007) Influência de diferentes tipos de estacas e substratos na propagação assexuada de hortênsia [Hydrangea macrophylla (Thunb.) Ser.]. Ciência e Agrotecnologia 31 (3):699-703.

Manuad M (2004) Enraizamento de estacas de azaleia tratadas com concentrações de ANA em diferentes substratos. Ciência e Agrotecnologia 28(4):771-777.

Mazzini RB, Pivetta KFL, Romani GN, Bueno BF (2013) Vegetative propagation of Bauhinia $x$ blakeana, an ornamental sterile tree. Revista Árvore 37(2):219-229.

Neves SMAS, Neves RJ, Mercante MA (2011) Dinâmica da paisagem na região nordeste de Cáceres-MT, com suporte nas geotecnologias. In: Rodrigues SC. (ORG:). Paisagens do Pantanal e do Cerrado: fragilidades e potencialidades. Uberlândia: EDUFU. 153-178.

Pacheco JP, Franco ETH (2008) Substratos e estacas com e sem folhas no enraizamento de Luehea divaricata Mart. Ciência Rural 38(7):1900-1906.

Pereira GHA, Coutinho FS, Costa e Silva, RA, Loss, A (2012) Desenvolvimento de estacas de alamanda amarela sob diferentes concentrações de ácido indolbutírico. Comunicata Scientiae 3(1): 16-22.

Pires EJP, Biasi LA (2003) Propagação da videira. In: Pommer CV. Uva: tecnologia da produção, pós-colheita e mercado. Porto Alegre: Cinco Continentes. 295-350p.

Pivetta KFL, Pedrinho DR, Fávero S, Batista GS, Mazzini RB (2012) Época de coleta e ácido indolbutírico no enraizamento de estacas de espirradeira (Nerium oleander L.). Revista Árvore 36(1):17-23.
Pizzatto M, Wagner Júnior A, Luckmann D, Pirola K, Cassol DA, Mazaro SM (2011) Influência do uso do AIB, época de coleta e tamanho de estaca na propagação vegetativa de hibisco por estaquia. Revista Ceres 58:4877-4892.

Ribeiro MNO, Paiva PDO, Silva JCB, Paiva R (2007). Efeito do ácido indolbutírico sobre estacas apicais e medianas de quaresmeira (Tibouchina fothergillae Cogn.). Revista Brasileira de Horticultura Ornamental 13:73-78.

Roberto SR, Pereira FM, Neves CSVJ, Jubileu BS, Azevedo MCB (2004) Enraizamento de estacas herbáceas dos porta-enxertos de videira 'Campinas' (IAC 766) e 'Jales' (IAC) 572 em diferentes substratos. Ciência Rural 34(5):1633-1636.

Santos JP, Davide AC, Teixeira LAF, Melo AJS, Melo LA (2011). Enraizamento de estacas lenhosas de espécies florestais. Cerne 17:293-301.

Sarzi I, Pivetta KFL (2005). Efeito das estações do ano e do ácido indolbutírico no enraizamento de estacas de variedades de mini-roseira (Rosa spp.). Científica 33(1):62-68.

Souza JCAV, Barroso DG, Carneiro JGA, Teixeira SL, Balbinot E (2009). Propagação vegetativa de cedro-australiano (Toonaciliata M. Roemer) por miniestaquia. Revista Árvore 33(2):205-213.

Specht CD, John Kress W, Stevenson DW, Desalle R (2001). A Molecular Phylogeny of Costaceae (Zingiberales). Molecular Phylogenetics and Evolution 21(3):333-345. 